\title{
APLIKASI MODEL RASCH DALAM PENGUJIAN ALAT UKUR KESEHATAN MENTAL DI TEMPAT KERJA
}

\author{
Rahmat Aziz \\ azirahma@psi.uin-malang.ac.id \\ Fakultas Psikologi \\ Universitas Islam Negeri (UIN) Malang
}

\begin{abstract}
This research aims to examine the validity and reliability of mental health scale in the workplace by using the Rasch model approach as well as compare the results of analysis with classical test theory approach. The subject were 60 employees at the State Islamic University Malang. The analysis showed that the mental health scale in the workplace is declared valid and reliable either by using the approach of Rasch model and classical test theory. This means that both approaches are able to find the same results on the test of mental health scale in the workplace.
\end{abstract}

Keyword: mental health, Rasch model, classical test theory

PSIKOISLAMIKA. Jurnal Psikologi Islam (JPI) copyright ๔ 2015 Pusat Penelitan dan Layanan Psikologi. Volume 12. Nomor 2, Tahun 2015

\section{PENDAHULUAN}

Universitas Islam Negeri Maulana Malik Ibrahim (UIN Maliki) Malang adalah institusi atau lembaga pendidikan tinggi yang telah mendapat pengakuan dari masyarakat luas, baik tingkat regional, nasional, bahkan internasional. Hal ini dibuktikan dengan semakin banyaknya minat masyarakat baik dari dalam negeri maupun luar negeri untuk menempuh pendidikan tinggi di UIN Maliki Malang. Pengakuan masyarakat tersebut, tidak terlepas dari kinerja dan produktivitas para civitas akademik baik dari jajaran pimpinan, dosen, maupun karyawannya. Dengan kata lain, kualitas produktivitas kerja menjadi faktor penting bagi kekuatan dan keberlanjutan UIN Malang sebagai sebuah lembaga pendidikan atau organisasi yang telah dipercaya masyarakat.

Banyak faktor yang dapat diduga menjadi penyebab produktivitas kerja. Penelitian tentang produktivitas dalam kegiatan orginasasi telah dilakukan oleh Koopman et.al (2002) yang berdasarkan hasil penelitiannya menemukan bahwa produktivitas kerja dipengaruhi oleh banyak faktor baik yang secara langsung maupun yang tidak langsung. Dalam penelitiannya tersebut, mereka menemukan bahwa kesehatan mental mempunyai peran yang sangat penting dan strategis dalam menciptakan budaya organisasi yang efektif dan efisien.

Kajian tentang kesehatan mental memang merupakan suatu kajian yang menarik dan penting untuk diteliti karena pada dasarnya setiap orang selalu mendambakan kesehatan dalam hidupnya. Dalam pandangan psikologi, kesehatan mental dapat didefinisikan menjadi dua pola yaitu pertama pola negatif yang mendefinisikan kesehatan mental sebagai suatu kondisi terhindarnya seseorang dari segala gangguan neurosis dan psikosis. Pola kedua adalah bersifat positif yang mendefinisikan kesehatan mental sebagai kemampuan individu dalam penyesuaian diri sendiri dan terhadap lingkungan sosialnya (Veit and Ware, 1983).

Ada beberapa alasan mengapa kesehatan mental menjadi isu penting dalam dunia kerja. Danna dan Griffin (1999) menyatakan alasan pentingnya kesehatan mental di tempat kerja, yaitu; pertama, pengalaman individu baik fisik, emosional, mental, atau sosial akan mempengaruhi 
bagaimana individu di tempat kerja. Kedua, kesehatan mental pekerja menjadi bagian penting karena akan menumbuhkan kesadaran terhadap faktor-faktor lain yang menimbulkan resiko bagi pekerja. Misalkan, karakteristik tempat kerja yang mendukung keamanan dan kessejahteraan bagi pekerja, potensi ancaman kekerasan atau agresi di tempat kerja (kekerasan seksual dan bentuk-bentuk perilaku disfungsional lainnya), bahkan hubungan antara pimpinan dan bawahan yang berimplikasi pada kesehatan mental. Ketiga, kesehatan mental menjadi bagian penting karena kesehatan yang lemah akan mempengaruhi kinerja.

Beberapa penelitian tentang kesehatan mental telah banyak dilakukan. Banyak penelitian-penelitian yang mengangkat fenomena tersebut dari berbagai perspektif, baik perspektif fisik, sosial, emosional, maupun mental (Danna \& Griffin, 1999; Marchan, Durand, \& Harvey, 2014; Rees, Breen, Cusack, \& Hegney, 2015). Peneliti lain dilakukan oleh Park, Attenweiler, \& Rieck, (2012) yang meneliti tentang kesehatan mental pada mahasiswa.

Penelitian tentang kesehatan mental yang memfokuskan pada pengembangan alat ukur juga telah dilakukan. Misalnya penelitian yang dilakukan oleh Johnson (2010) yang meneliti tentang reliabilitas inventori kesehatan mental pada orang yang mempunyai masalah serius tentang kesehatan mentalnya. Peneliti lain dilakukan oleh Walker, Thorne, Powers, \& Gaonkar (2010) yang mengembangkan alat ukur kesehatan mental.

Penelitian tentang penggunaan model Rasch sebagai salah satu program berbasis komputer dalam pengujian alat ukur juga telah banyak dilakukan diantaranya penelitian yang dilakukan oleh Phillipson, (2008) yang menggunakan pendekatan model Rasch dalam mengukur prestasi, penelitian lainnya dilakukan oleh Maat, (2015) yang menggunakan model Rasch dalam pengukuran tes matematika, penelitian tentang harga diri telah dilakukan widhiarso (2013) dan peneliti Stephens, (2014) yang menggunakan pendekatan model Rasch dalam menguji kepuasan siswa terhadap layanan akademik. Sejauh ini penelitian tentang pengembangan alat ukur tentang kesehatan mental di tempat kerja masih sangat jarang dilakukan, apalagi dengan menggunakan pendekatan model Rasch.

Pemodelan Rasch muncul dari analisis yang dilakukan oleh Dr Georg Rasch pada hasil ujian yang dia lakukan sendiri. la melakukan dua buah test pada siswa SD kelas 4, 5 dan 6. Hasilnya ditemukan bahwa siswa kelas 6 lebih sedikit membuat kesalahan dibandingkan dengan kelas 4 dan 5 atas soal yang sama. Kemudian dia menggambarkan grafik untuk menampilkan hasil dari kedua test tersebut, dan mendapati bahwa galat (error) dari satu tes berhubungan dengan 1,2 galat pada tes yang lain, perbandingkan yang sama pada ketiga kelas yang diuji. Artinya derajat kesulitan antara kedua tes sudah didapatkan. Supaya konstanta rasio ini terjadi, peluang untuk menjawab soal dengan betul haruslah sama ketika ketika kemampuan siswa sama dengan tingkat kesulitan soal. Dengan kata lain siswa mempunyai peluang kesempatan $50 \%$ menjawab dengan betul ketika kemampuan siswa sama dengan tingkat kesulitan soal (Bond and Fox, 2007).

Menurut Sumintono \& Widhiarso (2014) keunggulan pemodelan Rasch dibanding metoda lainnya, khususnya teori tes klasik, yaitu kemampuan melakukan prediksi terhadap data yang hilang (missing data), yang didasarkan kepala pola respon yang sistematis. Hal ini jelas menjadikan hasil analisis statistik yang lebih akurat dalam penelitian yang dilakukan, dan yang lebih penting lagi, pemodelan Rasch mampu menghasilkan nilai pengukuran standar error untuk instrumen yang digunakan yang dapat meningkatkan ketepatan perhitungan. Selanjutnya untuk memperjelas hasil analisis Rasch dalam tulisan ini, dibuat laporan hasil pengujian validitas dan reliabilitas item yang dilakukan dengan pendekatan teori tes klasik, yang dalam praktiknya berupa analisis yang bertujuan untuk mengkorelasikan antara skor dari suatu item dengan skor pada perangkat item (item total correlation) yang biasanya dihitung dengan korelasi point-biserial atau korelasi product moment. Hal ini dilakukan untuk membandingkan dan memperjelas hasil analisis model Rasch tentang kesehatan mental di tempat kerja pada karywan UIN Malang.

\section{KERANGKA KERJA TEORITIK}

Organisasi Kesehatan Dunia (World Health Organization) mendefinisikan kesehatan mental " a state of well-being in which the individual realizes his or her own abilities, can cope with the normal stresses of life, can work productively and fruitfully, and is able to make a contribution to his or her community “. Pada definisi tersebut dapat dipahami bahwa kesehatan mental diartikan sebagai kondisi sejahtera yang dirasakan individu, di mana dia menyadari kemampuannya, dapat mengatasi tekanan-tekanan dalam kehidupannya, 
dapat bekerja secara baik dan produktif, serta mampu memberi kontribusi kepada masyarakatnya (Organization \& others, 2004).

Definisi lain tentang kesehatan mental dikemukakan juga telah dikemukakan oleh Taylor \& Brown (1988) yang menyatakan bahwa, manusia yang memiliki kesehatan mental yang baik adalah manusia yang memiliki kemampuan menerima dirinya dan lingkungannya tanpa merasa kecewa dan mengeluh. Mereka dapat menerima sifat-sifat yang ada pada dirinya yang mungkin berbeda dengan gambaran ideal dirinya tanpa merasa terbebani.

Pendapat lain dikemukakan oleh Keyes (2002) menyatakan bahwa kesehatan mental memberi kontribusi penting bagi status kesehatan seseorang secara menyeluruh. Kesehatan mental bukan hanya tidak adanya penyakit mental tetapi lebih pada keadaan mental yang sejahtera. Sejalan dengan pendapat diatas dikemukakan oleh Veit and Ware (1983) menyatakan bahwa keadaan mental yang sejahtera sebagai indikator kesehatan mental itu mencakup dua aspek, yaitu pertama aspek terbebasnya individu dari tekanan psikologi (psychological distres) yang dicirikan dengan tingginya tinggkat kecemasan, depresi dan kehilangan kontrol; kedua, terdapatnya kesejahteraan psikologi (psikologi well-being) yang dicirikan dengan adanya perasaan positif secara umum, kondisi emosional dan kepuasan hidup.

Dari beberapa definisi tentang kesehatan mental yang telah dikemukakan tersebut dapat disimpulkan bahwa kesehatan mental merupakan keadaan di mana individu merasa sejahtera. Kesehatan mental yang baik ditunjukkan dengan 1) Kemampuan individu untuk mengetahui potensi dirinya dan mampu memaksimalkan potensinya; 2) Kemampuan individu mengatasi kondisi-kondisi yang menekan dalam hidupnya; 3) Kemampuan individu untuk bekerja secara produktif dan bermanfaat di tempat kerja, keluarga, komunitas, dan di antara teman. Karena itu, kesehatan mental dalam konteks di tempat kerja, dapat dijelaskan bahwa individu yang sehat mentalnya adalah individu yang mampu mewujudkan keserasian antara fungsi-fungsi kejiwaan, mampu menyesuaikan dengan dirinya sendiri dan lingkungannya, sehingga menjadi individu yang produktif dan mampu memberi kontribusi positif di tempat kerja.

Menurut Punch (2009) riset kuantitatif dalam ilmu sosial lebih dulu dikenal dibandingkan penelitian kualitatif. Pada masa 1800-an dimana kemajuan sains yang pesat menyebabkan ilmu-limu sosial tertarik untuk menerapkan kaidah yang digunakan dalam ilmu fisika, kimia dan biologi, yaitu dalam hal eksperimentasi dan pengukuran (measurement). Dalam aspek pertama dalam ilmu sosial dikenal disain penelitian berupa eksperimen, kuasi eksperimen dan survey (Creswell, 2012); sedangkan pada aspek kedua memunculkan teori tes klasik (classical test theory atau (TT) yang digagas oleh Spearman pada tahun 1904 (Alagumalai et al., 2005), serta pendefinisian pengukuran oleh Stevens pada 1946 (Mari et al., 2012) yang diterapkan secara luas pada berbagai ilmu-ilmu sosial.

Terdapat berbagai kritik yang dialamatkan pada CTT. Diantara berbagai kritik tersebut telah disampaikan oleh Schumaker (dalam Alagumalai et al., 2005) yang menyebutkan bahwa koefisien reliabilitas $\mathrm{CT}$ tergantung pada banyaknya sampel, skala pengukuran yang tidak linear, keterbatasan rentang skor serta keseimbangan korelasi negatifpositif. Bila dilihat definisi dari Stevens (Mari et al., 2012) pun jelas disebutkan bahwa jenis data yang didapat melalui teknik pengukuran yang menanyakan opini atau sikap, adalah nominal dan ordinal sehingga alat analisis yang bisa digunakan pun terbatas. Bahkan operasi aritmatika dasar seperti tambah, kurang, kali dan bagi pun tidak bisa dilakukan karena angka yang didapatkan bukan bilangan bulat namun skor yang berupa data ordinal. Kekurangan pendekatan teori tes klasik kemudian diperbaiki dengan teori respon butir (item response theory atau IRT) dengan berbagai variasi parameter logistiknya (PL), salah satunya adalah $1 \mathrm{PL}$ yang dikembangkan menjadi model rasch. Tidak seperti pendekatan teori tes klasik yang selalu bergantung pada skor, IRT tidak tergantung pada sampel soal/ pernyataan tertentu dan abilitas orang yang terlibat dalam ujian/survey.

Georg Rasch mengembangkan satu model analisis dari Item Response Theory pada tahun 1960-an biasa disebut $1 \mathrm{PL}$ yang berarti satu parameter logistic (Olsen, 2003). Model matematika ini kemudian dipopulerkan oleh Ben Wright (Linacre, 2011). Dengan data mentah berupa data dikotomi (berbentuk benar dan salah) yang mengindikasikan kemampuan siswa, Rasch memformulasikan hal ini menjadi satu model yang menghubungan antara siswa dan aitem (Sumintono \& Widhiarso, 2013). Sebagai ilustrasi, seorang siswa yang mampu mengerjakan $80 \%$ soal dengan benar tentu mempunyai abilitas yang lebih baik dari siswa lain yang hanya bisa mengerjakan $65 \%$ soal. Data tersebut (persentase) menunjukkan bahwa data mentah yang diperoleh tidak lain adalah jenis data ordinal yang menunjukkan peringkat dan 
tidak linier (Linacre, 1999).

Menurut Sumintono \& Widhiarso (2014) ada beberapa kesulitan dalam aplikasi pemodelan Rasch untuk melakukan analisis, penjelasan dan kesimpulan dari data satu ujian atau kuesioner survey yang ada. Intinya adalah kembali kepada defisini yang diberikan oleh George Rasch. Pola respon yang diberikan menunjukkan validitas dari tiap responden (person) kepada setiap butir soal (item). Sehingga hal ini menyebabkan pemodelan Rasch mampu menetapkan validitas konsep dari setiap butir soal. Suatu butir soal atau aitem, dikatakan valid ketika dia mampu untuk membedakan antara responden yang mampu dengan yang tidak mampu. Selanjutnya mereka menjelaskan adanya dua kemungkinan yang perlu dibahas lebih lanjut akan hal ini.

1. Kemungkinan pertama adalah ketidaksesuaian responden yang terlibat dalam ujian yang diberikan (atau partisipan dalam survey kuesioner), hal ini karena hasil yang diberikannya memang tidak sesuai dengan yang diharapkan. Pemodelan Rasch dapat mendeteksi adanya responden yang memang tidak sesuai dilibatkan dalam pengumpulan data dan dapat mengemukakan argumen kenapa dia perlu dikeluarkan karena tidak sesuai dengan model yang ada. Temuan ini jelas akan berkontribusi secara penting dalam riset yang dijalankan. Tidak seperti halnya dalam praktek pengolahan data statistik tradisional yang dilakukan tidak dapat diketahui secara pasti, namun dalam pemodelan Rasch akan muncul dengan sendirinya.

2. Kemungkinan kedua adalah sehubungan dengan butir soal atau aitem yang digunakan. Bila ternyata respon yang didapati bahwa terdapat aitem tidak dapat membedakan responden kemampuan responden; antara yang mampu dan yang tidak mampu, maka butir soal tersebut perlu untuk direvisi ulang atau malah aitem yang bersangkutan dibuang saja. Dalam suatu kondisi ekstrem tertentu dimana hasil yang didapat sangat tidak sesuai, maka kita perlu memperbaiki semua butir soal yang ada atau memperbaiki semua pernyataan karena memang tidak mengukur apa yang seharusnya diukur (validitas disangsikan). Hal ini jelas menunjukkan bahwa pemodelan Rasch tidak sekedar mengukur reliabilitas item saja, namun juga menguji validitas konsep interumen yang digunakan.

Selanjutnya Sumintono \& Widhiarso (2014) menyatakan bahwa pengujian responden (person) dan butir soal (item) secara bersamaan menunjukkan bahwa riset kuantitatif seperti yang biasa dilakukan oleh disiplim ilmu sains, juga dapat dilakukan hal yang sama dengan disiplin ilmu pengetahuan sosial yang biasanya diidentikan dengan riset kualitatif. Konsekuensi berikutnya adalah asumsi peringkat yang dibuat saat kuesioner dikonsepkan ataupun butir soal yang disusun, melalui pemodelan Rasch ini dapat diverifikasi apakah memang hal ini menghasilkan pola yang diharapkan atau tidak. Bentuk kalibrasi ini sangat unik dan hanya didapati pada pemodelan Rasch saja, dimana hal ini modelnya sama seperti persyaratan kalibrasi yang harus dipenuhi dalam pengukuran oleh instrumen dalam disiplin ilmu sains dalam melakukan kalibrasi pada skala pengukurannya. Dengan kata lain, kalibrasi dilakukan dalam pemodelan Rasch secara sekaligus dalam tiga hal, yaitu skala pengukuran, responden (person), dan butir soal (item). Suatu instrumen yang tidak dikalibrasi maka mempunyai kemungkinan menghasilkan data yang tidak valid dan bisa menyebabkan kegiatan riset yang dilakukan mengalami kegagalan.

Kajian tentang kesehatan mental dalam bidang psikologi menjadi kajian yang menarik dan berkembang pesat. Organisasi Kesehatan Dunia (World Health Organization) mendefinisikan kesehatan mental "a state of well-being in which the individual realizes his or her own abilities, can cope with the normal stresses of life, can work productively and fruitfully, and is able to make a contribution to his or her community ". Pada definisi tersebut dapat dipahami bahwa kesehatan mental diartikan sebagai kondisi sejahtera yang dirasakan individu, di mana dia menyadari kemampuannya, dapat mengatasi tekanan-tekanan dalam kehidupannya, dapat bekerja secara baik dan produktif, serta mampu memberi kontribusi kepada masyarakatnya (Organization \& others, 2004).

Definisi lain tentang kesehatan mental dikemukakan juga oleh Taylor \& Brown (1988) yang menyatakan bahwa, manusia yang memiliki kesehatan mental adalah manusia yang memiliki kemampuan menerima dirinya dan lingkungannya tanpa merasa kecewa dan mengeluh. Mereka dapat menerima sifat-sifat yang ada pada dirinya yang mungkin berbeda dengan gambaran ideal dirinya tanpa merasa terbebani.

Pendapat lain dikemukakan oleh Keyes (2002) menyatakan bahwa kesehatan mental memberi kontribusi penting bagi status kesehatan seseorang 
secara menyeluruh. Kesehatan mental bukan hanya tidak adanya penyakit mental tetapi lebih pada keadaan mental yang sejahtera. Sejalan dengan pendapat diatas dikemukakan oleh Veit and Ware (1983) menyatakan bahwa keadaan mental yang sejahtera sebagai indikator kesehatan mental itu mencakup dua aspek, yaitu pertama aspek terbebasnya individu dari tekanan psikologi (psychological distres) yang dicirikan dengan tingginya tinggkat kecemasan, depresi dan kehilangan kontrol; kedua, terdapatnya kesejahteraan psikologi (psikologi well-being) yang dicirikan dengan adanya perasaan positif secara umum, kondisi emosional dan kepuasan hidup.

Dari beberapa definisi tentang kesehatan mental yang telah dikemukakan tersebut dapat disimpulkan bahwa kesehatan mental merupakan keadaan di mana individu merasa sejahtera. Kesehatan mental yang baik ditunjukkan dengan 1) Kemampuan individu untuk mengetahui potensi dirinya dan mampu memaksimalkan potensinya; 2) Kemampuan individu mengatasi kondisi-kondisi yang menekan dalam hidupnya; 3) Kemampuan individu untuk bekerja secara produktif dan bermanfaat di tempat kerja, keluarga, komunitas, dan di antara teman. Karena itu, kesehatan mental dalam konteks di tempat kerja, dapat dijelaskan bahwa individu yang sehat mentalnya adalah individu yang mampu mewujudkan keserasian antara fungsi-fungsi kejiwaan, mampu menyesuaikan dengan dirinya sendiri dan lingkungannya, sehingga menjadi individu yang produktif dan mampu memberi kontribusi positif di tempat kerja.

\section{METODE}

Populasi dalam penelitian ini adalah karyawan Universitas Islam Negeri (UIN) Maulana Malik Ibrahim Malang. Subjek penelitian diambil dari karyawan yang berasal berbagai fakultas, rektorat dan perpustakaan yang berada di lingkungan Universitas Islam Negeri (UIN) Maulana Malik Ibrahim Malang. Dari data yang diperoleh dapat diketahui bahwa subjek usia termuda adalah 22 tahun dan usia tertua adalah 50 tahun. Selanjutnya komposisi subjek penelitian berdasarkan perbedaan jenis kelamin dapat dirinci sebagai berikut:

Tabel 1. Komposisi Subjek Penelitian Berdasarkan Jenis Kelamin

\begin{tabular}{|c|c|c|}
\hline \multirow{2}{*}{ Jenis kelamin } & \multicolumn{2}{|c|}{ Jumlah } \\
\hline & Subjek & $\%$ \\
\hline Laki-laki & 34 & 56.67 \\
\hline Perempuan & 26 & 43.33 \\
\hline Jumlah & 60 & $100 \%$ \\
\hline
\end{tabular}

Dari tabel diatas dapat diketahui bahwa dari jumlah 60 subjek. Dari jumlah tersebut lakilaki sebanyak 34 orang $(56,67 \%)$ dan perempuan sebanyak 26 orang $(43,33 \%)$. Selanjutnya komposisi subjek penelitian berdasarkan perbedaan status pekerjaan sebagai PNS atau Non-PNS dapat dirinci sebagai berikut:

Tabel 2. Komposisi Subjek Penelitian Berdasarkan Status Pekerjaan

\begin{tabular}{|c|c|c|}
\hline \multirow{2}{*}{ Status Pekerjaan } & \multicolumn{2}{|c|}{ Jumlah } \\
\hline & Subjek & $\%$ \\
\hline Sebagai PNS & 20 & 33.33 \\
\hline Sebagai Non-PNS & 40 & 66.67 \\
\hline Jumlah & 60 & $100 \%$ \\
\hline
\end{tabular}

Dari tabel diatas dapat diketahui bahwa dari jumlah 60 subjek tersebut yang berstatus sebagai PNS sebanyak 20 orang $(33,33 \%)$ Non-PNS sebanyak 40 orang $(66,67 \%)$. Selanjutnya komposisi subjek penelitian berdasarkan masa kerja yang dianggap lama (lebih dari 10 tahun) dan masa kerja yang dianggap belum lama (kurang dari 10 tahun) dapat dirinci sebagai berikut:

Tabel 3. Komposisi Subjek Penelitian Berdasarkan Masa Kerja

\begin{tabular}{llc}
\hline \multirow{2}{*}{ Masa kerja } & \multicolumn{2}{c}{ Jumlah } \\
\cline { 2 - 3 } & \multicolumn{1}{c}{ Subjek } & $\%$ \\
\hline Lebih dari 10 tahun & 17 & 28.33 \\
\hline Kurang dari 10 tahun & 43 & 71.67 \\
\hline Jumlah & 60 & $100 \%$ \\
\hline
\end{tabular}

Dari tabel diatas dapat diketahui bahwa dari jumlah tersebut yang masa kerjanya lebih dari 10 tahun sebanyak 17 orang $(28,33 \%)$ dan kurang dari 10 tahun sebanyak 43 orang $(71,67 \%)$.

Jenis skala yang digunakan pada penelitian ini adalah skala likert yang digunakan untuk mengukur variabel kesehatan mental. Definisi dan pengukuran dari variabel tersebut adalah sebagai berikut: Kesehatan mental diartikan sebagai terwujudnya keserasian antara fungsi kejiwaan dan terciptanya penyesuaian diri antara individu dengan dirinya dan lingkungannya. Data kesehatan mental ini diperoleh melalui alat ukur modifikasi penulis terhadap alat ukur The Mental Health Inventory (MHI-38) yang telah dibuat oleh Veit and Ware (1983). Aspek yang diungkap oleh alat ukur ini adalah kondisi kesehatan mental positif (perasaan positif secara umum, kondisi emosional atau rasa cinta, dan kepuasan hidup) dan kondisi kesehatan mental negatif (kecemasan, depresi, dan hilangnya 
kontrol perilaku dan emosi). Alat ukur ini berupa skala likert yang jawabannya berupa pilihan dengan enam alternatif jawaban.

Proses modifikasi alat ukur dilakukan dengan menggunakan beberapa cara, diantaranya adalah:

1. Mengurangi jumlah item. Maksudnya jumlah item pada mental Health Inventory (MHI) semula adalah 38 item tapi pada skala ini dikurangi menjadi 24 item yang terdiri dari 6 sub-variabel (indikator).

2. Menambah jumlah item. Maksudnya jumlah item pada mental health inventory (MHI) semual komposisi antar indikatornya tidak seimbang, ada yang banyak ada yang sedikit. Misalnya untuk indikator kepuasan hidup jumlahnya hanya 1 item padahal untuk indikator depresi jumlahnya ada 19 item karena itu pada skala ini jumlahnya diseimbangkan sehingga menjadi 4 item untuk masing-masing indikator.

3. Merubah redaksi item. Maksudnya ada item item yang redaksi bahasanya kurang cocok untuk subjek karyawan di UIN Malang karena itu redaksinya dirubah menjadi lebih kontekstual. Namun demikian, ada juga item yang redaksinya sesuai dengan aslinya.

4. Mengurangi alternatif jawaban yang sebelumnya berjumlah 6 pilihan dirubah menjadi 4 alternatif pilihan yaitu hampir setiap saat, sering sekali, jarang, dan tidak pernah.

Tabel 4. Sebaran item skala kesehatan mental

\begin{tabular}{|c|c|c|c|}
\hline \multirow{2}{*}{ Aspek } & \multirow{2}{*}{ Indikator } & \multicolumn{2}{|l|}{ Item } \\
\hline & & Nomor & Jumlah \\
\hline \multirow{3}{*}{ Negatif } & Cemas & $01,02,03,04$ & 4 \\
\hline & Depresi & $05,06,07,08$ & 4 \\
\hline & $\begin{array}{l}\mathrm{Hil} \text { a ng } \\
\text { control }\end{array}$ & $09,10,11,12$ & 4 \\
\hline \multirow{3}{*}{ Positif } & Emosi & $13,14,15,16$ & 4 \\
\hline & Cinta & $17,18,19,20$ & 4 \\
\hline & Puas & $21,22,23,24$ & 4 \\
\hline Jumlah & & & 24 \\
\hline
\end{tabular}

Teknik analisis data yang dilakukan terdiri dari dua jenis yaitu analisis dengan menggunakan pendekatan teori tes klasik dan pendekatan model Rasch. Penjelasan kedua pendekatan tersebut adalah:

1. Pengujian validitas dan reliabilitas dengan menggunakan pendekatan teori tes klasik yang dalam praktiknya berusaha mengkorelasikan antara item total dengan skor tiap item.
Semakin tinggi koefisen korelasinya maka semakin tinggi tingkat validitas itemnya. Selanjutnya, untuk pengujian reliabilitasnya menggunakan formula alfa Cronbach. Suatu alat ukur penelitian dapat dikatakan reliabel jika mendapatkan nilai @ lebih dari 0,600.

2. Pengujian dengan pendekatan model Rasch dengan menggunakan program winsteps. Salah satu perbedaannya dengan model teori tes klasik adalah selain memperhatikan item juga memperhatikan aspek responden dan menghitung besaran korelasinya. Hasil output analisis program winsteps yang ditampilkan adalah:

a. Item measure yang bertujuan untuk mengetahui kualitas tiap item dengan cara mengukur logit item yang diuji.

b. Person measure yang bertujuan untuk mengetahui kualitas person dengan cara mengukut logit person yang diuji.

c. Variable maps yang bertujuan untuk menjelaskan peta person dan item yang diuji.

d. Scalogram yang bertujuan melihat hasil analisis dalam bentuk scalogram (gambar dalam bentuk skala).

e. Summary statistic yang bertujuan untuk mengetahui secara keseluruhan kualitas respon dan item sekaligus juga interkasi yang terjadi antara keduanya.

\section{HASIL DAN PEMBAHASAN}

Skala kesehatan mental yang dikembangkan dalam penelitian ini merupakan alat ukur hasil proses modifikasi (mengurangi, menambahi dan merubah) item dari skala Mental Health Inventory. Hasil selengkapnya tentang pengujian reliabilitas data terhadap skala kesehatan mental adalah sebagai berikut:

1. Hasil pengujian reliabilitas skala kesehatan mental pada aspek kecemasan diperoleh nilai a sebesar 0,726 . Dari 4 aitem yang diuji dinyatakan tiga item yang valid dengan koefisien korelasi aitem berkisar antara 0,457 sampai 0,653 dan satu item dinyatakan gugur (item nomor 1) karena koefisien korelasinya kurang dari 0,300 .

2. Hasil pengujian reliabilitas skala kesehatan mental pada aspek depresi diperoleh nilai a sebesar 0,617. Dari 4 aitem yang diuji dinyatakan tiga item yang valid dengan koefisien korelasi aitem berkisar antara 0,391 sampai 0,450 
dan satu item dinyatakan gugur (item nomor

2) karena koefisien korelasinya kurang dari 0,300 .

3. Hasil pengujian reliabilitas skala kesehatan mental pada aspek kehilangan kontrol diperoleh nilai a sebesar 0,712 . Dari 4 aitem yang diuji dinyatakan semunya valid dengan koefisien korelasi aitem berkisar antara 0,486 sampai 0,554 .

4. Hasil pengujian reliabilitas skala kesehatan mental pada aspek emosi diperoleh nilai a sebesar 0,761 . Dari 4 aitem yang diuji dinyatakan semunya valid dengan koefisien korelasi aitem berkisar antara 0,502 sampai 0,662.

5. Hasil pengujian reliabilitas skala kesehatan mental pada aspek afeksi (cinta) diperoleh nilai a sebesar 0,784. Dari 4 aitem yang diuji dinyatakan semuanya valid dengan koefisien korelasi aitem berkisar antara 0,513 sampai 0,738 .

6. Hasil pengujian reliabilitas skala kesehatan mental pada aspek kepuasan hidup diperoleh nilai a sebesar 0,862 . Dari 4 aitem yang diuji dinyatakan semunya valid dengan koefisien korelasi aitem berkisar antara 0,685 sampai 0,748 .

Hasil pengujian reliabilitas skala kesehatan mental pada semua aspek diperoleh nilai a sebesar 0,888 . Dari 24 aitem yang diuji dinyatakan 22 item valid dan 2 item gugur, dengan koefisien korelasi aitem berkisar antara 0,333 sampai 0,713. Dari hasil pengujian di atas dapat disimpulkan bahwa skala yang diuji telah memenuhi persyaratan metodologis sehingga dapat digunakan dalam penelitian. Untuk memperjelas hasil diatas dapat dilihat pada tabel berikut:

Tabel 5. Hasil pengujian validitas dan reliabilitas berdasarkan teori tes klasik

\begin{tabular}{|c|c|c|c|c|}
\hline \multirow{2}{*}{ Nama Variabel } & \multicolumn{3}{|l|}{ Item } & \multirow{2}{*}{ - Reliabilitas } \\
\hline & Semula & Valid & Gugur & \\
\hline $\begin{array}{l}\text { Kesehatan } \\
\text { Mental }\end{array}$ & 24 & 22 & 2 & 0,888 \\
\hline Kecemasan & 4 & 3 & 1 & 0,726 \\
\hline Depresi & 4 & 3 & 1 & 0,617 \\
\hline $\begin{array}{ll}\text { - } & \text { Kehilangan } \\
\text { kontrol }\end{array}$ & 4 & 4 & 0 & 0,712 \\
\hline $\begin{array}{ll} & \text { Emosi } \\
& \text { Positif } \\
\end{array}$ & 4 & 4 & 0 & 0,761 \\
\hline $\begin{array}{ll}\text { Afektif } \\
\text { (cinta) }\end{array}$ & 4 & 4 & 0 & 0,748 \\
\hline - Kepuasan & 4 & 4 & 0 & 0.862 \\
\hline
\end{tabular}

Dari tabel diatas dapat diketahui bahwa variabel kesehatan mental mempunyai tingkat reliaabilitas yang paling tinggi @ 0,888 dibanding masing-masing indikatornya. Selanjutnya secara berurutan tingginya reliabilitas aspek kesehatan mental adalah aspke kepuasan hidup, emosi positif, afeksi, kehilangan kontrol, kecemasan, dan depresi.

Selanjutnya hasil analisis alat ukur kesehatan mental pada karyawan Universitas Islam Negeri (UIN) Maulana Malik Ibrahim malang berdasarkan pengujian model Rasch (summary statistik, item measure, person measure, dan scalogram) ditemukan hasil sebagai berikut:

1. Berdasarkan hasil analisis yang diperoleh dari summary statistik diperoleh informasi sebagai berikut:

a. Person measure yang diperoleh 1.50 menunjukkan rata-rata nilai responden dalam instrumen kesehatan mental. Nilai rata-rata yang lebih tinggi dari logit 0,0 menunjukkan kecenderungan responden yang lebih banyak menjawab sangat setuju pada pernyataan di berbagai item. Khusus untuk jawaban pada aspek tekanan psikologis (depresi, cemas, dan hilang kontrol) datanya terlebih dahulu dirubah, yang sebelumnya unfaforable dirubah menjadi favorable.

b. Nilai alpha Cronbach yang diperoleh sebesar 0,88 artinya reliabilitas yang diperoleh alat ukur ini tinggi. Nilai ini merupakan ukuran reliabilitas yang dalam praktik pengukurannya berupa interaksi antara person dan item secara keseluruhan.

c. Nilai person reliability diperoleh angka 0.88 dan item reliability 0.89 . Hal ini dapat disimpulkan bahwa konsistensi jawaban dari responden dan kualitas item dalam instrumen adalah tinggi.

d. Pengelompokkan person dan item dapat diketahui dari nilai separation. Makin besar nilai separation maka kualitas instrumen dalam hal keseluruhan responden dan item makin bagus karena mampu mengidentifikasi kelompok responden dan item. Nilai person separation yang diperoleh adalah 2,71 (dibulatkan menjadi 3) dan nilai item separation adalah 2,84 (dibulatkan menjadi 3 ) artinya ada 3 kelompok responden dan 3 kelompok item. 
2. Berdasarkan hasil analisis yang diperoleh dari item measure diperoleh informasi sebagai berikut:

3. Dari total count yang diperoleh menunjukkan bahwa semua item menunjukkan angka 60 artinya tidak ada data yang hilang dalam analisis karena jumlah subjek yang diteliti berjumlah 60 orang.

4. Item yang paling mudah disetujui oleh responden adalah item nomor $\mathrm{C} 1$ (kesehatan mental aspek kecemasan 1) karena nilai logit item menunjukkan angka 2,20 yang merupakan item dengan nilai logit tertinggi.

5. Item yang paling susah disetujui oleh responden adalah item nomor $\mathrm{H} 1$ (kesehatan mental aspek kehilangan kontrol 1) karena nilai logit item menunjukkan angka -1.56 yang merupakan item dengan nilai logit terendah.

6. Berdasarkan hasil analisis yang diperoleh dari person measure diperoleh informasi sebagai berikut:

a. Responden dengan nomor 24 menunjukkan logit person sebesar 4,02. Hal ini berati bahwa responden tersebut mempunyai kecenderungan tingkat kesehatan mental yang tinggi dibanding yang lainnya.

b. Responden dengan nomor 36 menunjukkan logit person sebesar $-0,86$. Hal ini berati bahwa responden tersebut mempunyai kecenderungan tingkat kesehatan mental yang rendah dibanding yang lainnya.

c. Semua responden menunjukkan total count sebesar 24. Hal ini berati bahwa semua responden menjawab dengan lengkap skala kesehatan mental yang diberikan (tidak ada item yang tidak terjawab).

7. Berdasarkan hasil analisis yang diperoleh dari scalogram diperoleh informasi bahwa tidak ditemukan responden yang menunjukkan person fit order. Hal ini berarti bahwa responden semuanya menjawab item dengan konsisten (tidak ada yang menjawab asal-asalan).

Berdasarkan hasil uji validitas terhadap alat ukur kesehatan mental dengan menggunakan teori tes klasik dapat disimpulkan bhawa semua item yang diuji dinyatakan valid karena mempunyai koefisien korelasi diatas 0,300. Demikian juga hasil analisis tiap sub-variabel (kecemasan, depresi, kehilangan kontrol, emosi positif, afeksi atau cinta, dan kepuasan hidup) menunjukkan hasil yang valid dan reliabel. Hanya saja untuk sub-variabel kecemasan dan depresi jumlah item yang valid masing-masing hanya berjumlah 3 item karena ada item yang koefisien korelasinya kurang dari 0,300.

Item yang dinyatakan tidak valid untuk aspek kecemasan adalah item nomor 1 yang bunyinya adalah: Dalam sebulan terakhir, seberapa sering Anda menemukan diri anda berusaha dan mencoba untuk tenang. Berdasarkan hasil di atas dapat diduga bahwa item tersebut membingungkan bagi subjek untuk dijawab secara konsisten dengan item yang lain karena seolah-olah ada dua pernyataan yang diukur pada item tersebut yaitu berusaha dan mencoba.

Item yang dinyatakan tidak valid untuk aspek depresi adalah item nomor 2 yang bunyinya adalah: Dalam sebulan terakhir, seberapa sering Anda menghabiskan waktu untuk merenungi sesuatu yang negatif. Berdasarkan hasil diatas diduga bahwa item tersebut membingungkan bagi subjek untuk dijawab secara konsisten dengan item yang lain karena kalimat "sesuatu yang negatif" dapat diartikan dengan berbagai interpretasi sehingga menjadi ambigu.

Untuk menjelaskan hasil diatas, maka berdasarkan pendapat Peacock, Ervin, \& Daly (2009) yang menyatakan bahwa individu yang memiliki keterbatasan kemampuan penalaran akan kesulitan memahami butir pernyataan di dalam skala. Akibat kesalahan memahami pernyataan tersebut pola respons mereka kurang bisa dimodelkan. Kedua, responden memiliki strategi tertentu dalam merespons butir pernyataan, misalnya respons yang mengandung kepatutan sosial. Pada butir yang dinilai sensitif, mereka akan berusaha menunjukkan bahwa mereka adalah individu yang ideal dalam kaca mata sosial, namun pada butir yang tidak terlalu sensitif mereka memberikan respons yang jujur.

Selain itu, menurut Fisher (1993). Menyatakan bahwa ada responden yang kurang memiliki motivasi dalam merespons skala. Rendahnya motivasi ini menyebabkan mereka memberikan respons asalasalan. Dampaknya adalah respons mereka bervariasi dan tidak konsisten, tergantung pada mood mereka saat merespons butir. Namun demikian dari hasil analisis diatas dapat disimpulkan bahwa alat ukur kesehatan mental, baik secara keseluruhan maupun tiap sub-variabel dari kesehatan mental yang diajukan adalah baik dan cocok digunakan untuk mengukur kesehatan mental pada karyawan Universitas Islam Negeri (UIN) Maulana Malik Ibrahim Malang.

Selanjutnya hasil pengujian reliabilitas yang ditemukan ternyata jauh lebih tinggi dari persyaratan yang ditentukan yaitu 0,600 . Baik ketika diuji 
secara keseluruhan (24 item) maupun ketika diuji berdasarkan sub-variabel kesehatan mental. Hal ini berarti alat ukur yang diajukan telah memenuhi persyaratan reliabilitas alat ukur menurut pendekatan teori tes klasik.

Hasil pengujian diatas dapat disimpulkan bahwa ke 14 item yang dibuat untuk mengukur kesehatan mental dapat digunakan untuk penelitian penelitian lebih lanjut tentang kesehatan mental pada sivitas akademika UIN Malang. Hanya saja untuk bahan pertimbangan, perlu diperhatikan tentang format yang dibuat dapat digunakan dengan berbagai macam jenis sehingga tidak terkesan menjenuhkan dan membosankan bagi subjek yang mengisi instrumen tersebut.

Selanjutnya hasil analisis alat ukur dengan menggunakan pendekatan model Rasch menemukan bahwa nilai reliabilitas alat ukur kesehatan mental yang diperoleh sebesar 0,88 . Hal ini berarti bahwa alat ukur yang diuji mempunyai tingkat reliabilitas yang tinggi. Hasil ini menarik untuk dicermati karena nilai yang diperoleh adalah sama antara hasil pengujian dengan pendekatan classical test teory dan hasil dari pengujian model Rasch yaitu 0,888 dan 0,88 .

Hasil pengujian separation terhadap person dan item menunjukkan bahwa alat ukur ini mampu mengelompokkan person dan item ke dalam 3

\section{DAFTAR PUSTAKA}

Alagumalai, S., Curtis, D.D. and Hungi, N. (editors) (2005). Applied Rasch Measurement: book of exemplars. papers in honour of John P. Keeves. Dordrecth: Springer.

Bond, T.G., \& Fox, C. (2007). Applying the Rasch Model. Fundamental measurement in the Human Sciences. Lawrence Erlbaum Associates, Publishers. Mahwah. kelompok. Selanjutnya hasil pengujian misfit ditemukan bahwa responden penelitian dalam menjawab item dilakukan secara konsisten. Hasil ini menunjukkan bahwa item yang dibuat adalah bagus.

Hasil pengujian item measure menunjukkan bahwa ada dua item yang dipersepsi atau diduga terlalu mudah atau terlalu sulit oleh subjek penelitian adalah item kesehatan mental aspek kecemasan (item 1) dan item kesehatan mental aspek depresi (item 2). Hal ini berarti bahwa hasil yang diperoleh dari pengujian model Rasch adalah sama dengan hasil pengujian pada teori tes klasik.

Hasil pengujian person measure pada aspek total count menunjukkan angka sebesar 24 artinya semua item yang diuji telah dijawab oleh subjek penelitian (tidak ada item yang tidak terjawab). Hal ini berarti bahwa item yang dibuat cukup memberikan daya tarik untuk dijawab atau mungkin juga subjek penelitiannya adalah orang yang serius dan sungguh-sungguh dalam mengisi alat ukur kesehatan mental yang diberikan.

Dari uraian-uraian diatas dapat disimpulkan bahwa kedua pendekatan yang digunakan dalam menguji alat ukur kesehatan mental pada karyawan UIN Malang memberikan hasil yang konsisten, dan menghasilkan suatu kesimpulan bahwa alat ukur yang diuji adalah alat ukur yang bagus sehingga dapat digunakapdalam penelitian selanjutnya.

Creswell, J.W. (2012). Educational Research: planning, conducting and evaluating quantitative and qualitative research. Boston: Pearson.

Danna, K., \& Griffin, R. W. (1999). Health and wellbeing in the workplace: A review and synthesis of the literature. Journal of Management, 25(3), 357-384.

Fisher, R. J. (1993). Social Desirability Bias and the Validity of Indirect Questioning. Journal of Consumer Research, 20(2), 303-315. 


\section{Lampiran.}

\section{Skala Kesehatan Mental}

Gambarkanlah kondisi diri anda SEJAK SEBULAN TERAKHIR sampai SAAT INI untuk menjawab pertanyaan SEBERAPA SERING mengalami kondisi yang dirasakan di TEMPAT KERJA, dengan cara memilih salah satu angka pada kolom di bawah ini yang paling sesuai dengan keadaan Anda.

\begin{tabular}{|c|c|c|c|c|c|c|}
\hline 4 & : & \multicolumn{5}{|l|}{ Hampir Setiap saat } \\
\hline 3 & : & \multicolumn{5}{|l|}{ Sering sekali } \\
\hline$(2$ & : & \multicolumn{5}{|l|}{ Jarang } \\
\hline (1) & : & \multicolumn{5}{|l|}{ Tidak pernah } \\
\hline \multicolumn{7}{|c|}{$\begin{array}{l}\text { Bagian } 3 \\
\text { DALAM SEBULAN TERAKHIR.... }\end{array}$} \\
\hline 1 & & Seberapa sering Anda menemukan diri Anda berusaha dan mencoba untuk tenang? & 4 & 3 & 2 & (1) \\
\hline 2 & & Seberapa sering Anda menjadi "nervous" ketika menghadapi situasi yang tidak diharapkan? & 4 & 3 & 2 & (1) \\
\hline 3 & & Seberapa sering Anda mendapatkan diri Anda sebagai orang yang bingung atau frustasi? & 4 & 3 & 2 & (1) \\
\hline 4 & & Seberapa sering Anda merasakan sebagai orang yang lelah atau merasa tak berdaya? & 4 & 3 & 2 & (1) \\
\hline 5 & & Seberapa sering Anda mearasa berada pada titik yang terendah? & 4 & 3 & 2 & (1) \\
\hline 6 & & Seberapa sering Anda menghabiskan waktu untuk merenungi sesuatu yang negatif? & 4 & 3 & 2 & (1) \\
\hline 7 & & Seberapa sering Anda menggunakan waktu untuk menikmati rasanya putus asa atau kelabu? & 4 & 3 & 2 & (1) \\
\hline 8 & & Seberapa sering Anda merasa sia-sia dalam melakukan aktivitas sehari-hari? & 4 & 3 & 2 & (1) \\
\hline 9 & & Seberapa sering Anda merasa bahwa orang lain akan lebih baik jika Anda sudah mati? & 4 & 3 & 2 & (1) \\
\hline 10 & & $\begin{array}{l}\text { Seberapa sering Anda merasa kehilangan kontrol terhadap pikiran, perasaan, dan perilaku } \\
\text { anda? }\end{array}$ & 4 & 3 & 2 & (1) \\
\hline 11 & & Seberapa sering Anda merasa Tidak mempunyai apa-apa dalam menatap masa depan? & 4 & 3 & 2 & (1) \\
\hline 12 & & Seberapa sering Anda merasa ingin menangis ketika menghadapi masalah? & 4 & 3 & 2 & (1) \\
\hline 13 & & $\begin{array}{l}\text { Seberapa sering Anda merasakan bahwa masa depan terlihat penuh harapan dan } \\
\text { menjanjikan? }\end{array}$ & 4 & 3 & 2 & (1) \\
\hline 14 & & Seberapa sering kehidupan sehari-hari Anda penuh dengan hal-hal yang menarik? & 4 & 3 & 2 & (1) \\
\hline 15 & & Seberapa sering Anda merasa santai dan bebas dari ketegangan? & 4 & 3 & 2 & (1) \\
\hline 16 & & Seberapa sering pada umumnya Anda menikmati hal yang dilakukan? & 4 & 3 & 2 & (1) \\
\hline 17 & & Seberapa sering Anda merasa dicintai dan diinginkan? & 4 & 3 & 2 & (1) \\
\hline 18 & & Seberapa sering Anda merasakan bahwa mencintai dan dicintai terasa penuh dan sempurna? & 4 & 3 & 2 & (1) \\
\hline 19 & & Seberapa sering Anda merasa nyaman berkomunikasi dengan kolega Anda? & 4 & 3 & 2 & (1) \\
\hline
\end{tabular}




\begin{tabular}{|c|c|c|c|c|c|}
\hline 20 & Seberapa sering perlakuan kolega yang membuat Anda merasa bahagia? & 4 & 3 & 2 & - \\
\hline 21 & Seberapa sering Anda merasa bahagia dalam menjalani kehidupan ini? & 4 & 3 & 2 & - \\
\hline 22 & Seberapa sering Anda merasa puas dalam melakukan kegiatan sehari-hari? & 4 & 3 & 2 & - \\
\hline 23 & Seberapa sering Anda menikmati apa yang terjadi dalam kehidupan ini? & 4 & 3 & 2 & - \\
\hline 24 & Seberapa sering Anda merasa bergairah dalam melakukan aktivitas sehari-hari? & 4 & 3 & 2 & - \\
\hline
\end{tabular}

